(c) American Dairy Science Association, 2005.

\title{
Developmental Gene Expression of Lactoferrin and Effect of Dietary Iron on Gene Regulation of Lactoferrin in Mouse Mammary Gland*
}

\author{
Y. Wang, ${ }^{\star}$ Y. Tu, F. Han, Z. Xu, and J. Wang \\ The Key Laboratory of Molecular Animal Nutrition, Ministry of Education, Institute of Feed Science, \\ Zhejiang University, Hangzhou 310029, China
}

\begin{abstract}
This study evaluated the developmental gene expression of lactoferrin (LF) and the effect of supplementary iron on gene expression of LF in the mammary gland of mice using semi-quantitative reverse transcriptionpolymerase chain reaction (RT-PCR) analysis. In experiment 1 , a total of 12 female mice were used to determine the effect of different lactating stages on mRNA expression of LF. The Institute of Cancer Research mice were divided into 4 groups; each group of 3 mice was tested on d 1, 9, 17, and 25 of lactation. In experiment 2, 6 groups of mice (total of 24 female mice at d 12 after mating) were fed purified diets (without iron or supplement iron) and were assigned to 2 treatments (control and treatment). The experimental feeding period lasted $35 \mathrm{~d}$. During the feeding experiment, 6 mice (3 animals in each group) were chosen on d 1, 9, 17, and 25 of lactation to determine the effect of iron on LF mRNA expression of mice at different stages of lactation. The results of experiment 1 showed that LF mRNA had strong expression on d 1 of lactation, decreased gradually on $\mathrm{d} 9$ and 17 of lactation, and then increased again markedly on $\mathrm{d} 25$ of lactation. These results imply that the expression of LF in the mammary gland at different lactating stages is consistent with the changes in LF concentrations in milk. Iron significantly increased LF mRNA expression on 1 and 25 of lactation. Iron did not statistically increase LF gene expression on $\mathrm{d} 9$ and 17 of lactation. These findings raised the possibility that iron supplementation may play a role in regulation of $\mathrm{LF}$ levels in vivo.
\end{abstract}

(Key words: lactoferrin, mouse, gene expression, regulation)

Abbreviation key: LF = lactoferrin, RT-PCR = reverse transcription-PCR.

Received December 6, 2004.

Accepted January 25, 2005.

Corresponding author: Y. Z. Wang; e-mail: yzwang@zju.edu.cn.

* Supported by the National Basic Research Programme (2004CB117500) and Provincial Natural Science Foundation of Zhejing (RC01053).

\section{INTRODUCTION}

Lactoferrin (LF), discovered originally in milk (Masson and Heremans, 1971), is a 78-kDa member of the transferrin family of iron-binding glycoproteins (Aisen and Listowsky, 1980; Metz Boutigue et al., 1984). Lactoferrin is expressed and secreted by glandular epithelial cells (Masson et al., 1966) and is found at lower levels in bodily excretion fluids such as tears, saliva, and mucosal and genital excretions, but it is found in high concentrations in milk of most species (Heremans and Schonne, 1969; Kussendrager, 1986; Yu and Chen, 1993). Mouse colostrum contains approximately 1 g/L of LF (Leclercq et al., 1987). Lactoferrin has been associated with a wide variety of biologically important processes, including regulation of iron metabolism (Iyer and Lonnerdal, 1993), protection against microbial infection (Weinberg, 1984), curbing the proliferation of fungi (Arnold et al., 1980) and viruses (Lu et al., 1987), cellular growth promotion (Hashizume et al., 1987), and regulation of immune function (Machnicki et al., 1993). Moreover, it has an extended role in the body's defense mechanism through its immune modulatory actions (Zucali et al., 1989).

The various functions of $L F$ have received extensive attention, especially host defense and resistance against infections in mammary gland (Bullen et al., 1987; Tsui et al., 1990; Shimizu et al., 1996). The level of this protective action depends on the amount of LF in milk. In general, the amount of LF in milk varies with the different stages of lactation; it is high in colostrum and lower, by an order of magnitude, at full lactation (Klosba et al., 1976). It was reported that LF mRNA concentrations in bovine mammary tissue were quite low $2 \mathrm{~d}$ before parturition and during lactation but were high $3 \mathrm{~d}$ after the cessation of milking (Goodman and Schanbacher, 1991). Yet few reports have appeared in the literature concerning the levels of LF mRNA in mouse mammary gland tissues at different stages of lactation. Therefore, this study was conducted to measure the concentration of LF mRNA in samples of total mammary RNA prepared from mice at different stages of lactation. Specifically, the experiments were designed to determine whether the concentrations of 
Table 1. Composition of purified diet.

\begin{tabular}{lcc}
\hline Ingredient & Control & $\begin{array}{l}\text { Treatment } \\
\text { group }\end{array}$ \\
\cline { 2 - 2 } Corn starch & 39.0 & $\mathrm{~g} / 100 \mathrm{~g})$ \\
\cline { 2 - 3 } Casein & 26.0 & 39.0 \\
Alpha-starch & 10.0 & 26.0 \\
Cellulose & 5.0 & 10.0 \\
Soybean oil & 6.0 & 5.0 \\
Sucrose & 5.0 & 6.0 \\
Dicalcium phosphate & 5.0 & 5.0 \\
Mineral mix 1 & 3.5 & 5.0 \\
Mineral mix 2 & - & - \\
Vitamin mix & & 3.5 \\
\hline
\end{tabular}

${ }^{\mathrm{a}}$ Contained $56.8 \mathrm{~g}$ of $\mathrm{MgSO}_{4} \cdot 7 \mathrm{H}_{2} \mathrm{O}, 14.1 \mathrm{~g}$ of $\mathrm{NaCl}, 26.4 \mathrm{~g}$ of $\mathrm{KCl}$, $0.7 \mathrm{~g}$ of $\mathrm{MnSO}_{4} \cdot \mathrm{H}_{2} \mathrm{O}, 0.1 \mathrm{~g}$ of $\mathrm{CuSO}_{4} \cdot 5 \mathrm{H}_{2} \mathrm{O}, 0.4 \mathrm{~g}$ of $\mathrm{ZnSO}_{4} \cdot 7 \mathrm{H}_{2} \mathrm{O}$, $0.001 \mathrm{~g}$ of $\mathrm{Na}_{2} \mathrm{SeO}_{3}$, and $0.001 \mathrm{~g}$ of $\mathrm{KI} / 100 \mathrm{~g}$.

${ }^{\mathrm{b}}$ Contained $56.8 \mathrm{~g}$ of $\mathrm{MgSO}_{4} \cdot 7 \mathrm{H}_{2} \mathrm{O}, 14.1 \mathrm{~g}$ of $\mathrm{NaCl}, 26.4 \mathrm{~g}$ of $\mathrm{KCl}$, $0.7 \mathrm{~g}$ of $\mathrm{MnSO}_{4} \cdot \mathrm{H}_{2} \mathrm{O}, 0.1 \mathrm{~g}$ of $\mathrm{CuSO}_{4} \cdot 5 \mathrm{H}_{2} \mathrm{O}, 0.4 \mathrm{~g}$ of $\mathrm{ZnSO}_{4} \cdot 7 \mathrm{H}_{2} \mathrm{O}$, $0.001 \mathrm{~g}$ of $\mathrm{Na}_{2} \mathrm{SeO}_{3}, 0.001 \mathrm{~g}$ of $\mathrm{KI}$ and $16.1 \mathrm{~g}$ of $\mathrm{FeSO}_{4} \cdot 7 \mathrm{H}_{2} \mathrm{O}(120 \mathrm{mg}$ $\mathrm{Fe} / \mathrm{kg}) / 100 \mathrm{~g}$.

${ }^{\mathrm{c}}$ Contained 480,000 units of vitamin A, 51,400 units of vitamin $\mathrm{D}_{3}$, $0.8 \mathrm{~g}$ of vitamin $\mathrm{E}$ acetate, $0.2 \mathrm{~g}$ of vitamin $\mathrm{K}_{3}, 0.4 \mathrm{~g}$ of vitamin $\mathrm{B}_{1}$, $0.4 \mathrm{~g}$ of vitamin $\mathrm{B}_{2}, 0.4 \mathrm{~g}$ of vitamin $\mathrm{B}_{6}, 2.05 \mathrm{~g}$ of nicotinic acid, 0.8 $\mathrm{g}$ of Ca-pantothate, $0.2 \mathrm{~g}$ of folic acid, $7 \mathrm{mg}$ of D-biotin, $0.8 \mathrm{mg}$ of vitamin $\mathrm{B}_{12}$, and $43 \mathrm{~g}$ of choline bitartrate/100 $\mathrm{g}$.

mammary LF mRNA changed in a pattern to match the changes in milk LF concentrations.

In addition, the protein structure of LF has binding sites of $\mathrm{Fe}^{3+}$ ions. It contributes to the major structurefunctional properties of LF. Some relevant genes (e.g., ferritin, transferrin receptor) have a specific 'iron regulator element' in the mRNA, and iron could up- or downregulate these gene expressions (Klausner et al., 1993). However, no reports were found concerning the effect of dietary iron on gene expression of LF. The second aim of the present study was to investigate whether changes in iron supplementation might modify the mRNA concentration of LF in mammary gland of lactating mice.

\section{MATERIALS AND METHODS}

\section{Animals and Purified Diets}

Female ICR mice were purchased from the animal center at the Zhejiang College of Traditional Chinese Medicine (Hangzhou, Zhejiang, China) and were maintained and bred in the animal center. They were treated following the institutional guidelines for the care and use of experimental animals. The 24 female mice were divided into 2 groups at random at d 12 after mating, were kept in individual cages, and were provided purified diet with food and water ad libitum. The composition of purified diets (except iron) is listed in Table 1. The difference was $0 \mathrm{mg} / \mathrm{kg}$ of $\mathrm{Fe}$ in the control diet and $120 \mathrm{mg} / \mathrm{kg}$ of $\mathrm{Fe}$ in the treatment diet.

\section{Tissue}

Mouse mammary gland samples were prepared from the female ICR mouse on $\mathrm{d} 1,9,17$, and 25 after parturition. At the indicated time, mice were killed by decapitation, and mammary gland tissues were aseptically removed and immediately frozen in liquid nitrogen for RNA isolation.

\section{Total RNA Extraction}

Total RNA was isolated from the maternal mammary gland tissues (entire mammary gland pulverized for the analysis) at the indicated time using TRIzol Reagent (Invitrogen Life Technologies, Carlsbad, CA) according to the manufacture's manual. After pulverization and homogenization of the tissue, the homogenate was extracted with chloroform and then precipitated by isopropanol. The resulting pellets of total RNA were dissolved in ultra pure water; the quantity and the quality of total RNA were measured by a spectrophotometer at 260 and $280 \mathrm{~nm}$.

\section{Reverse Transcription}

Two micrograms of total RNA were converted into cDNA; $2 \mu \mathrm{g}$ of total RNA and $2 \mu \mathrm{L}$ of random primers (500 $\mu \mathrm{g} / \mathrm{mL}$; Promega Corp., Madison, WI) were denatured at $70^{\circ} \mathrm{C}$ for $5 \mathrm{~min}$. The following components were added to give a total reaction volume of $25 \mu \mathrm{L}: 5 \mu \mathrm{L}$ MMLV $5 \times$ reaction buffer $(250 \mathrm{~m} M$ Tris $\cdot \mathrm{HCl}(\mathrm{pH} 8.3)$, $375 \mathrm{~m} M \mathrm{KCl}, 15 \mathrm{mM} \mathrm{MgCl}$, and $50 \mathrm{~m} M$ dithiothreitol), $2 \mu \mathrm{L}$ dNTP mix (10 mM each of dATP, dCTP, dGTP, and dTTP), and $1 \mu \mathrm{L}$ M-MLV reverse transcriptase [200 units $/ \mu \mathrm{L} ; 0.5 \mu \mathrm{L}$ rRNasin ribonuclease inhibitor and nuclease-free water (Promega Corp.)]. It was mixed gently by flicking the tube, and the reaction mixture was incubated at $37^{\circ} \mathrm{C}$ for $60 \mathrm{~min}$.

\section{Determination of the Number of PCR Cycles}

It is important to select the appropriate number of cycles so that the amplification product is not only clearly visible on an agarose gel and can be quantified, but is also in the exponential range and does not reach a plateau yet. One microliter of cDNA solution, obtained by reverse transcriptase reaction of total RNA, was used for templates of PCR amplification in a total volume of $50 \mu \mathrm{L}$. The optimum PCR primer concentration, $\mathrm{Mg}^{2+}$ concentration and annealing temperature to give a linear amplification of each transcript were determined by a preliminary experiment (data not shown). The PCR assay mixture contained the following components: $37.5 \mu \mathrm{L}$ nuclease-free water, $5 \mu \mathrm{L} 10 \times$ PCR reaction buffer, $3 \mu \mathrm{L} \mathrm{MgCl}_{2}(25 \mu \mathrm{M}), 1 \mu \mathrm{L}$ dNTP mix, $1 \mu \mathrm{L}$ 
Table 2. Specific primers of lactoferrin and $\beta$-actin gene.

\begin{tabular}{lll}
\hline Gene & Oligonucleotide sequence & $\begin{array}{l}\text { PCR product } \\
\text { (bp) }\end{array}$ \\
\hline Lactoferrin & 5'- GCTGGAGATGTGGCTTTTAC -3'(sense primer) & 897 \\
$\beta$ & 5'- CAGAGATTGGATTTGGGGTC -3'(antisense primer) & \\
& 5'- CGGGACCTGACCGACTACCT -3'(sense primer) & 411 \\
\hline
\end{tabular}

sense primer $(20 \mu M), 1 \mu \mathrm{L}$ antisense primer $(20 \mu M)$, and $0.5 \mu \mathrm{L}$ Taq DNA polymerase $(2 \mathrm{U} / \mu \mathrm{L}$; Promega Corp.). All subsequent amplification reaction steps were performed using a Gene Amp PCR system 9600. The PCR profile for murine LF included denaturation at $94^{\circ} \mathrm{C}$ for $2 \mathrm{~min}$, followed by different cycles of denaturation at $94^{\circ} \mathrm{C}$ for $50 \mathrm{~s}$, annealing at $55^{\circ} \mathrm{C}$ for $50 \mathrm{~s}$, extension at $72^{\circ} \mathrm{C}$ for $1 \mathrm{~min}$, and a final extension at $72^{\circ} \mathrm{C}$ for $10 \mathrm{~min}$. The PCR profile for $\beta$-actin was similar to that of LF, except that annealing was done at $58^{\circ} \mathrm{C}$. Oligonucleotide primers specific for murine LF and $\beta$ actin are based on known sequences deposited in Genebank and listed in Table 2. The PCR amplification products from mRNA were predicted to be 897 and $411 \mathrm{bp}$ for $L F$ and $\beta$-actin, respectively. The oligonucleotide primers used had been synthesized by Shanghai Sangon Biological Engineering Technology and Service Co. (Shanghai, China). The LF and $\beta$-actin PCR cycles were performed 23, 25, 27, 29, 31, 33, and 35 times, respectively, when the other PCR parameters were consistent. Then, the appropriate cycle numbers were confirmed.

\section{Reverse Transcription-PCR Assay}

The relative concentration of LF mRNA in different lactating stages and different groups were determined by the semi-quantitative reverse transcription-PCR (RT-PCR) method (Marone et al., 2001). An equal volume of one of the same sample cDNA was used for LF and $\beta$-actin PCR, respectively, as described previously. The component of PCR was the same as that described previously, and the incubation cycle was 29 cycles for $\mathrm{LF}$ and $\beta$-actin amplification.

A $5-\mu \mathrm{L}$ portion of each PCR product was subjected to electrophoresis on a $1.0 \%$ agarose gel with ethidium bromide. The PCR products were normalized according to the amount of $\beta$-actin detected in the same cDNA sample, and LF/ $\beta$-actin ratios were calculated. The expression level of LF gene in mouse mammary gland at different lactation stages and different groups were compared on the basis of LF-to- $\beta$-actin ratio.

\section{Data Analysis}

Electrophoresis band intensities of the PCR products were quantified using Image Master VDS software
(Amersham Pharmacia Biotech, Uppsala, Sweden). Mean LF mRNA expression levels normalized against $\beta$-actin levels from mammary gland tissue were presented in absolute integrated optical density. Each value was analyzed for statistical difference according to the Bonferroni/Dunn method. Differences between groups were analyzed by the Student $t$-test when 2 groups were analyzed, and ANOVA (Duncan, 1955) was used when more than 2 groups were analyzed.

\section{RESULTS}

\section{Number of PCR Cycles}

After amplification of mammary gland cDNA using specific primer for mouse LF and $\beta$-actin, PCR products were observed at 897 and $411 \mathrm{bp}$, respectively (Figure 1A, B). As shown in Figure 1, the band intensity of electrophoresis on a $1.0 \%$ agarose gel with ethidium bromide showed stronger positive signals by the increased cycle. Then, for the semi-quantification analysis, the amplification cycle was used for 29 cycles for $\mathrm{LF}$ and $\beta$-actin. Twenty-nine cycles of amplification were sufficient to allow the visualization of the LF messenger in the mouse lactating mammary gland, and it did not reach a plateau.

\section{LF Gene Expression in the Mammary Gland of Lactating Mice}

Reverse transcription-PCR was conducted on the total RNA extracted at 4 stages of lactating development (d 1, 9, 17, and 25 of lactation) from mouse mammary gland tissues. The constitutively expressed housekeeping gene $\beta$-actin was used as an internal control. Using primers for $\mathrm{LF}$ and $\beta$-actin, 2 bands were obtained from mouse mammary gland (897 and $411 \mathrm{bp}$ ) (Figure. 2).

Figure 2 displays the bands of mice LF and $\beta$-actin PCR product that were subjected to electrophoresis on a $1.0 \%$ agarose gel with ethidium bromide. The integrated optical density of LF and $\beta$-actin bands of mice was determined (Figure 3). The levels of LF mRNA in the mammary gland tissues were measured and corrected by that of $\beta$-actin mRNA, and the corrected values were used as an index of LF gene expression (Figure 3). 
A

$\begin{array}{lllllll}23 & 25 & 27 & 29 & 31 & 33 & 35\end{array}$

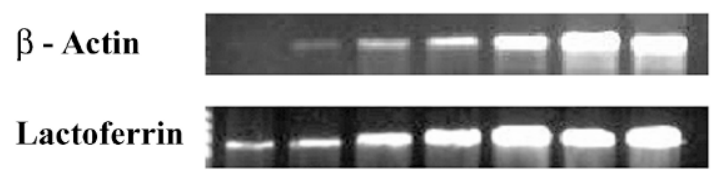

B



Figure 1. A) Electrophoresis result of lactoferrin and $\beta$-actin PCR products collected from cycles 23, 25, 27, 29, 31, 33, and 35 of mouse mammary gland tissue on a $1.0 \%$ agarose gel. B) Integrated optical density analysis of lactoferrin and $\beta$-actin PCR products at $23,25,27$, $29,31,33$, and 35 cycles. The bands were densitometrically quantified by Immage master VDS.

Reverse transcription-PCR analysis showed that the levels of LF mRNA in mice mammary gland tissues at different lactating stages varied in a biphasic manner. Lactoferrin mRNA levels decreased steadily between $d$ 1 after parturition and d 9 after parturition and were significantly lower at d 9 after parturition $(P<0.05)$. However, at d 17 after parturition, the level of LF mRNA also remained significantly lower than at $d$ after parturition $(P<0.05)$. But, no significant differences were detected in LF expression at d 17 after parturition compared with d 9 after parturition. Thereafter, LF gene expression increased significantly along with the involution of mammary gland tissue. The LF gene expression at $\mathrm{d} 25$ after parturition was markedly higher than at d 9 and 17 after parturition $(P<0.05)$. The gene expression of LF at $\mathrm{d} 25$ after parturition was not significantly higher than at $\mathrm{d} 1$ after parturition (Figure 3).

\section{Effect of Iron Supplementation on Gene Expression of LF}

The effect of dietary iron on mRNA concentration of LF in mammary gland tissues at different lactating stages was examined, and the results, presented in Figure 4, show that iron has an effect on LF gene expression and that supplemental iron improved the levels of LF mRNA at 4 stages after parturition. However, the increased levels of LF gene expression at these 4 stages are different. Compared with the control group, the increase in LF gene expression in mammary gland tissues in the treatment group was not significant at d 9 and 17 of lactation. But, at $\mathrm{d} 1$ and 25 after parturition, the expression of LF in the mammary gland increased greatly in response to supplemental iron $(P<0.05)$. The integrated optical density ratios of $L F$ to $\beta$-actin in mice on the control and treatment diets at different lactating stages are shown in Figure 5.

\section{DISCUSSION}

The mammary gland tissue has long been recognized as the major site of LF expression in the mouse and other animals (Groves, 1960). In the current experiment, developmental changes in LF mRNA levels at d $1,9,17$, and 25 after parturition in mammary gland tissues of female mice were evaluated by semi-quantitative PCR analysis. Reverse transcription PCR allows

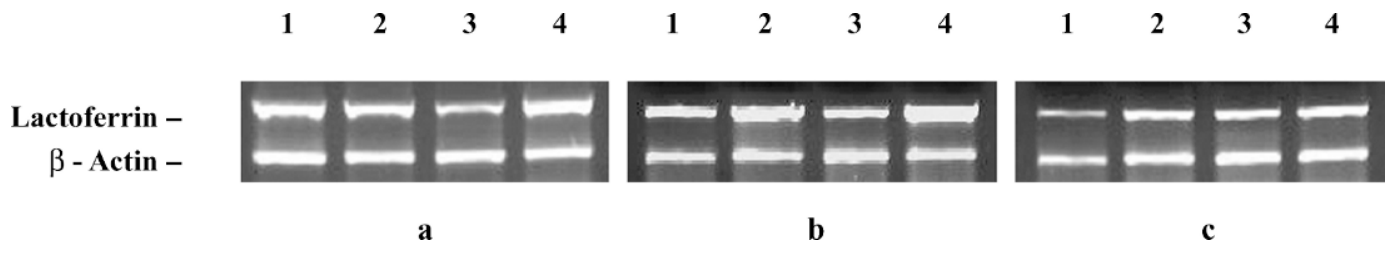

Figure 2. Developmental gene expression of lactoferrin in mammary gland tissue during lactation of mice was analyzed by RT-PCR. Amplified PCR products obtained with mRNA after reverse transcription were size-fractionated on a $1.0 \%$ agarose gel. The gel was stained with ethidium bromide, and PCR products were observed under UV light (Immage master VDS). Showing at the images were bands of the expected sizes of RT-PCR products of mouse lactoferrin $(\times 29$ PCR cycles) and $\beta$-actin $(\times 29$ PCR cycles), which was used as an internal control. Lanes 1 through $4=$ amplified PCR products of lactating mouse mammary gland tissue at d 1, 9, 17, and 25 of lactation, respectively. Three repetitions are represented by $a, b$, and $c$. 




Figure 3. The integrated optical density (IOD) ratio of lactoferrin and $\beta$-actin electrophoresis bands at different lactating stages. Densitometric analysis of mice lactoferrin was normalized to $\beta$-actin and is shown as lactoferrin-to- $\beta$-actin ratios. Cumulative results (mean \pm SEM) are shown in a histogram. The results are representative of 3 independent experiments using 3 mice. ${ }^{*} P<0.05$.

the relative quantification of LF mRNA levels of mammary gland tissues, although not the absolute quantification. The resulting 897 -bp amplification has been previously sequenced from mouse mammary gland and was $99 \%$ homologous to the known sequences of LF deposited in Genbank.
The present data clearly demonstrated that there are some variations in levels of mRNA encoding $\mathrm{LF}$ in mammary gland tissues, and the differences in LF expression were stage-dependent. Lactoferrin mRNA has strong expression at $d 1$ after parturition. Then, the amount decreased steadily at $\mathrm{d} 9$ and 17 after parturition. There are reports that the concentration of $\mathrm{LF}$ in milk varies with the different stages of lactation (i.e., it is high in colostrum and lower, by an order of magnitude, at full lactation) (Neville et al., 1998; Tsui et al., 1990). The results from the current experiment imply that the expression amount of LF in the mammary gland at different lactating stages is consistent with the changes in LF concentrations in milk. Research has suggested that LF is a major gene product in estrogen-stimulated mouse uterine tissue (Pentecost and Teng, 1987; Liu and Teng, 1992), and its gene expression was shown to be regulated by estrogen (Pentecost and Teng, 1987; Newbold et al., 1992). However, the regulation of estrogen to LF gene expression is tissue-specific. The synthesis of LF in mouse mammary gland is unaffected by estrogen, but is dependent on prolactin (Green and Pastewka, 1978; Liu and Teng, 1992).

In the current study, stronger LF mRNA expression was observed (Figure 2) during the later involution period of the mammary gland (at d 25 after parturition). At this time, it was likely to have other potential factors to regulate the expression of LF mRNA, except for prolactin. The result from Lee et al. (1996) also indicated that the stronger expression of LF was observed during mammary gland involution. The increasing of LF levels may contribute to the prevention of microbial infection

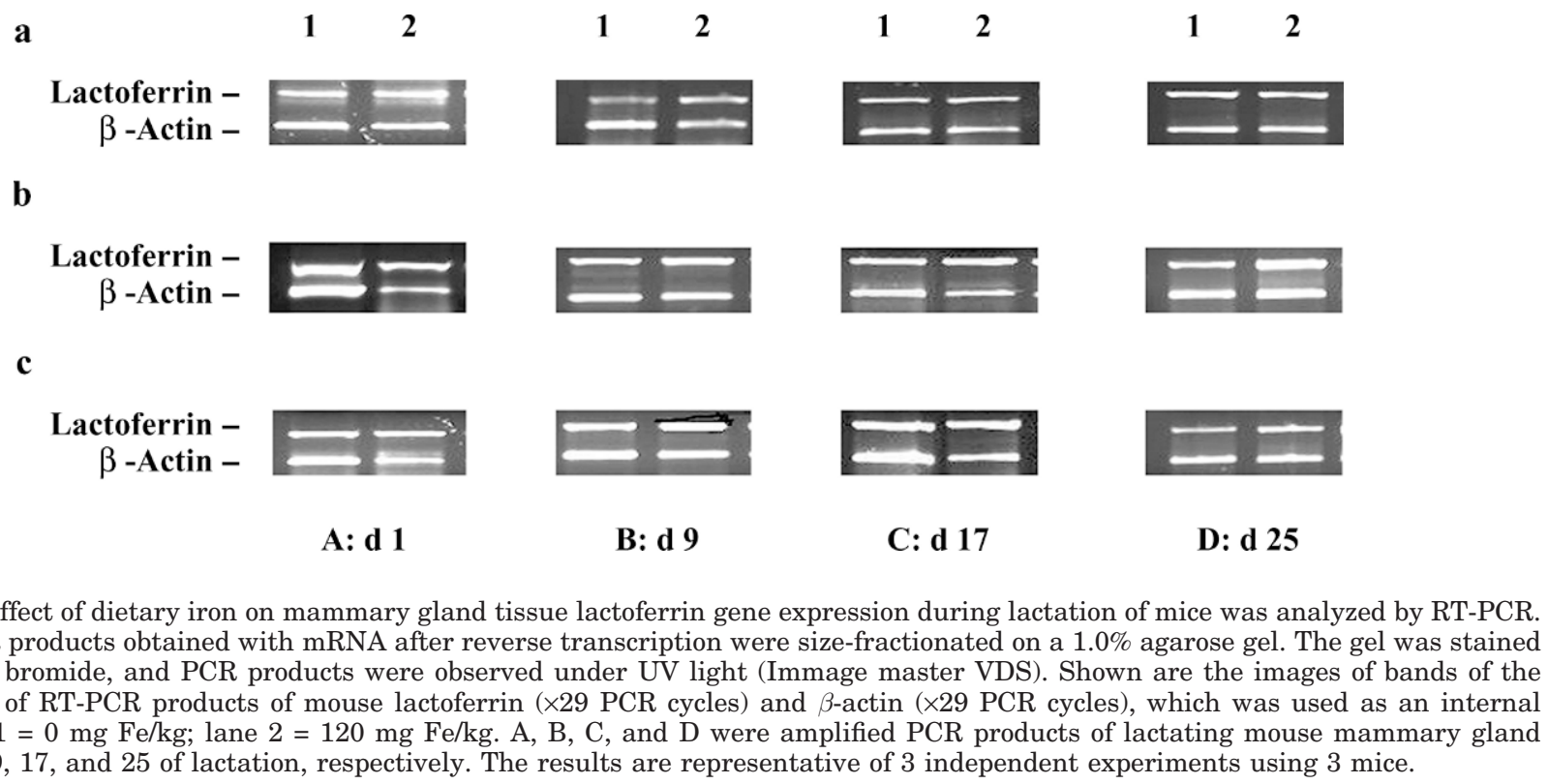




\section{$\square$ Control (0 mg Fe/kg) $\square$ Treatment (120 mg Fe/kg)}



Figure 5. The integrated optical density (IOD) ratio of each band of lactoferrin and $\beta$-actin of control and treatment mice at different lactating stage. Densitometric analysis of control and treatment mice lactoferrin were normalized to $\beta$-actin and is shown as lactoferrinto- $\beta$-actin ratios. Each column is the mean of 3 individual means $( \pm$ SEM $) * P<0.05$.

during mammary involution, at which stage the residual milk in the mammary gland provides good nutritional sources for microbial growth (Sanchez et al., 1992). Different regulation mechanisms of tissue and stage-specific LF gene expression should be studied in the future.

We further investigated the effect of dietary iron on gene expression of LF in vivo by semi-quantitative RTPCR. Our results showed that iron increased LF mRNA levels in the mammary gland of female mice during lactation. The levels of LF mRNA in the treatment group (120 $\mathrm{mg}$ of $\mathrm{Fe} / \mathrm{kg}$ ) were higher than in the control group ( $0 \mathrm{mg}$ of $\mathrm{Fe} / \mathrm{kg}$ ) at the 4 stages. The result of this study has some consistency with the review of Wang et al. (2002). Wang et al. (2002) investigated the effect of $\mathrm{Fe}^{3+}$ (100 to $1000 \mu \mathrm{M}$ of $\mathrm{FeCl}_{3}$ ) on the expression of rPLF (recombinant porcine LF) in a Pichia pastoris transformant in shake-flask cultures. Results revealed that addition of $\mathrm{Fe}^{3+}$ to $100 \mu M$ significantly enhanced the expression of rPLF without interfering with cell growth (Wang et al., 2002).

As a member of the transferrin gene family (Park et al., 1985), the iron-binding site and the overall struc- ture of LF are rather similar to those of the plasma iron-transport protein transferrin (Baker et al., 2002), but LF binds iron more tightly than transferrin (Bennett et al., 1981). The regulation of transferrin protein levels in the rats by iron has been well documented (Idzerda et al., 1986; Grigor et al., 1990). It was reported that the influence of iron on transferrin gene expression has connection with transferrin receptor. The biosynthesis of transferrin receptor can be regulated posttranscriptionally by iron in a common mechanism. It has been suggested that the number of transferrin receptors in the mammary gland will be up- or downregulated during iron deficiency or sufficiency, because it has a specific "iron regulator element" in its mRNA (Sigman and Lönnerdal, 1990).

Our results have also shown that the influence of dietary iron on LF gene expression was different at 4 stages of lactation. A marked increase in the expression of LF mRNA might occur at 1 and 25 after parturition. However, the influence of iron was not significant on the expression of LF mRNA at $d 9$ and 17 after parturition. It is possible that some regulation factors of LF gene expression were more sensitive at special physiology conditions (e.g., $1 \mathrm{~d}$ after parturition, involution period of mammary gland).

It is well known that iron is an essential element for normal body function, and it can affect a host of cell functions, such as gene regulation, DNA, and protein biosynthesis (Machnicki, 1991). The potential importance of iron to the gene can be appreciated from the facts that control of iron consumption occurs by downregulating the expression of iron-containing proteins under iron-restricted conditions (Andrews et al., 2003). It seems likely that such iron-dependent regulation of biosynthesis mediated by the iron-responsive element binding protein also occurs in LF receptors that existed in intestinal epithelial cells, which may be regulated in response to intracellular iron levels. Thus, the LF receptor may play a role in iron absorption (Hu et al., 1988). Further studies are needed to document whether $\mathrm{LF}$ receptor is present in the mammary gland of the mouse. If this is true, our present study suggests that the regulatory mechanism of iron to LF is realized by the effect of iron on LF receptor expression.

This study showed that LF mRNA concentration is high at the beginning and end of the lactation and low between these points and that LF mRNA concentrations can be increased by the addition of supplementary iron to the diet.

\section{ACKNOWLEDGMENTS}

This study was supported in part by the animal center at the College of Zhejiang Traditional Chinese Medi- 
cine, and we are grateful to the help of Director Minli Chen in the early part of this work.

\section{REFERENCES}

Aisen, P., and I. Listowsky. 1980. Iron transport and storage proteins. Annu. Rev. Biochem. 49:357-393.

Andrews, S. C., A. K. Robinson, and F. Rodríguez-Quiñones. 2003. Bacterial iron homeostasis. FEMS Microbiol. Rev. 27:215-237.

Arnold, P. R., M. Brewer, and J. J. Gauthier. 1980. Bactericidal activity of human lactoferrin: Sensitivity of a variety of microorganisms. Infect. Immun. 28:893-898.

Baker, E. N., H. M. Baker, and R. D. Kidd. 2002. Lactoferrin and transferrin: Functional variations on a common structural framework. Biochem. Cell Biol. 80:27-34.

Bennett, R. M., G. C. Bagby, and J. Davis. 1981. Calcium-dependent polymerization of lactoferrin. Biochem. Biophys. Res. Commun. 101:88-95

Bullen, J. J., H. J. Rogers, and E. Griffiths. 1987. Role of iron in bacterial infection. Curr. Top. Microbiol. Immunol. 80:1-35.

Duncan, D. B. 1955. Multiple range and multiple F tests. Biometrics 11:1-42.

Goodman, R. E., and F. L. Schanbacher. 1991. Bovine lactoferrin mRNA: Sequence, analysis, and expression in the mammary gland. Biochem. Biophys. Res. Commun. 180:75-84.

Green, M. R., and J. V. Pastewka. 1978. Lactoferrin is a marker for prolactin response in mouse mammary explants. Endocrinology 103:1510-1513.

Grigor, M. R., F. J. Mcdonald, N. Latta, C. L. Richardson, and W. P. Tate. 1990. Transferrin-gene expression in the rat mammary gland. Biochem. J. 267:815-819.

Groves, M. L. 1960. The isolation of a red protein from milk. J. Am. Chem. Soc. 82:3345-3350.

Hashizume, S., K. Kuroda, and H. Murakami. 1987. Cell culture assay of biological activity of lactoferrin and transferrin. Meth. Enzymol. 147:302-314.

Heremans, J. F., and E. Schonne. 1969. Lactoferrin, an iron-binding protein in neutrophilic leukocytes. J. Exp. Med. 130:643-658.

Hu, W. L., J. Mazurier, G. Sawatzki, J. Montreuil, and G. Spik. 1988. Lactotransferrin receptor of mouse small-intestinal brush border. Biochem. J. 249:435-441.

Idzerda, R. L., H. Huebers, C. A. Finch, and G. S. Mcknight. 1986. Rat transferrin gene expression: Tissue-specific regulation by iron deficiency. Proc. Natl. Acad. Sci. USA 83:3723-3727.

Iyer, S., and B. Lonnerdal. 1993. Lactoferrin, lactoferrin receptors and iron metabolism. Eur. J. Clin. Nutr. 47:232-241.

Klausner, R. D., T. A. Rouault, and J. B. Harford. 1993. Regulating the fate of mRNA: The control of cellular iron metabolism. Cell 72:19-28.

Klosba, F., B. Senft, F. Meyer, and U. E. Pfleiderer. 1976. Untersuchungen über Laktoferrin and Immunoglobulin G in der Kuhmikch, L. Mitteilung: Variabilität in der Konzentration während der Laktation. Züchtungskunde 48:278-288.

Kussendrager, K. 1986. Lactoferrin and lactoperoxidase bio-active milk proteins. Food Tech. Eur. 2(1):39-43.

Leclercq, Y., G. Sawatzki, J. M. Wieruszeski, J. Montreuil, and G. Spik. 1987. Primary structure of the glycans from mouse serum and milk transferrins. Biochem. J. 247:571-578.

Lee, M. J., H. Kim, D. Jeon, I. Hwang, B. Choi, K. Myung, H. Kim, Y. Choi, S. Paik, and M. Baik. 1996. Iron metabolism-related genes and mitochondrial are induced during involution of mouse mammary gland. Biochem. Biophys. Res. Commun. 224:164-168.

Liu, Y., and C. T. Teng. 1992. Estrogen response module of the mouse lactoferrin gene contains overlapping chicken ovalbumin up- stream promoter transcription factor and estrogen receptor binding elements. Mol. Endocrinol. 6:355-364.

Lu, L., G. Hangoc, A. Oliff, L. T.Chen, R.-N. Shen, and H. E. Broxmeyer. 1987. Protective influence of lactoferrin on mice infected with the polycythemia-inducing strain of friend virus complex. Cancer Res. 47:4184-4188.

Machnicki, M. 1991. Biological properties of lactoferrin. Folia Biologica 37:65-76.

Machnicki, M., M. Zimecki, and T. Zafulski. 1993. Lactoferrin regulates the release of tumour necrosis factor alpha and interleukin 6 in vivo. Int. J. Exp. Pathol. 74:433-439.

Marone, M., S. Mozzetti, D. D. Ritis, L. Pierelli, and G. Scambia. 2001. Semiquantitative RT-PCR analysis to assess the expression levels of multiple transcripts from the same sample. Biol. Proceedings Online 3(1):19-25.

Masson, P. L., and J. F. Heremans. 1971. Lactoferrin in milk from different species. Compara. Biochem. Physiol. 39:119-129.

Masson, P. L., J. F. Heremans, J. J. Prignot, and G. Wauters. 1966. Immunohistochemical localization and bacteriostatic properties of and iron binding protein from bronchial mucus. Thorax 21:538-544.

Metz Boutigue, M. H., J. Jolles, J. Mazurier, F. Schoentgen, D. Legrand, G. Spik, J. Montreuil, and P. Jolles. 1984. Human lactotransferrin amino acid sequence and structural comparisons with other transferrins. Eur. J. Biochem. 38:256-257.

Neville, M. C., K. Chatfield, L. Hausen, A. Lewis, J. Monks, J. Nuijens, M. Olliver-Bousquet, F. Schanbacher, and V. Sawicki. 1998. Lactoferrin secretion into mouse milk. Pages 141-143 in Advances in Lactoferrin Research. G. L. d. Spik, J. Mazurier, and A. Pierce, eds. Plenum Press, New York, NY.

Newbold, R. R., C. T. Teng, J. W. C. Beckman, W. N. Jefferson, R. B. Hanson, J. V. Miller, and J. A. Mclachlan. 1992. Fluctuations of lactoferrin protein and messenger ribonucleic acid in the reproductive tract of the mouse during the estrous cycle. Biol. Reprod. 47:903-915.

Park, I., E. Schaeffer, A. Sidoli, F. E. Baralle, G. N. Cohen, and M. M. Zakin. 1985. Organization of the human transferring gene: Direct evidence that it originated by gene duplication. Proc. Natl. Acad. Sci. USA 82:3149-3153.

Pentecost, B. T., and C. T. Teng. 1987. Lactotransferrin is the major estrogen inducible protein of mouse uterine secretions. J. Biol. Chem. 262:10134-10139.

Sanchez, L., M. Calvo, and J. H.Brock. 1992. Biological role of lactoferrin. Arch. Dis. Child. 67:657-661.

Shimizu, K., H. Matsuzawa, K. Okada, S. T. Azume, S. Dosako, Y. Kawasky, K. Hashimoto, and Y. Koga. 1996. Lactoferrin-mediated protection of the host from murine cytomegalovirus infection by a T-cell-dependent augmentation of natural killer cell activity. Arch. Firol. 141:1875-1889.

Sigman, M., B. Lönnerdal. 1990. Response of rat mammary gland transferrin receptors to maternal dietary iron during pregnancy and lactation. Am. J. Clin. Nutr. 52:446-450.

Tsui, S., Y. Hirata, F. Mukai, and S. Ohtagaki. 1990. Comparison of lactoferrin content in colostrums between different cattle breed. J. Dairy Sci. 73:125-128.

Wang, S. H., T. S. Yang, S. M. Lin, M. S. Tsai, and S. C. Wu. 2002. Expression, characterization, and purification of recombinant porcine lactoferrin in Pichia pastoris. Protein Expr. Purif. 25:41-49.

Weinberg, F. D. 1984. Iron withholding: A defense against infection and neoplasia. Physiol. Rev. 64:65-102.

Yu, L. C., and Y. H. Chen. 1993. The developmental profile of lactoferrin. Biochem. J. 296:107-111.

Zucali, J. R., H. E. Broxmeyer, D. Levy, and C. Morse. 1989. Lactoferrin decreases monocyte-induced fibroblast production of myeloid colony-stimulation activity by suppressing monocyte release of interleukin-1. Blood 74:1531-1536. 